\title{
New technologies from the bioworld: selection of biopolymer-producing microalgae
}

\author{
Roberta Guimarães Martins', Igor Severo Gonçalves², Michele Greque de Morais \\ and Jorge Alberto Vieira Costa ${ }^{1 *}$ \\ 'Laboratório de Engenharia Bioquímica, Escola de Química e Alimentos, \\ Universidade Federal do Rio Grande - FURG, Rio Grande, RS, Brazil \\ 'Laboratório de Microbiologia e Bioquímica, Escola de Química e Alimentos, \\ Universidade Federal do Rio Grande - FURG, Rio Grande, RS, Brazil \\ *jorgealbertovc@terra.com.br
}

\begin{abstract}
Microalgae are studied because of their biotechnological potential. The growth of microalgae aims at obtaining natural compounds. Due to the large amount of accumulated polymer waste, one of the solutions is the use of biodegradable polymers. The objective of this work was to select biopolymer-producing microalgae and to study the cell growth phase in which maximum production occurs. Microalgae Cyanobium sp., Nostoc ellipsosporum, Spirulina sp. LEB 18 and Synechococcus nidulans were studied. The growth was carried out in closed 2 L photobioreactors kept in a chamber

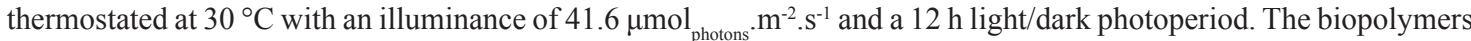
were extracted at times of 5, 10,15, 20 and $25 \mathrm{~d}$. The microalgae that had the highest yields were Nostoc ellipsosporum and Spirulina sp. LEB 18 with crude biopolymer efficiency of 19.27 and $20.62 \%$ in 10 and 15 d, respectively, at the maximum cell growth phase.
\end{abstract}

Keywords: cyanobacteria, biopolymer, polyhydroxyalkanoate, productivity.

\section{Introduction}

Cyanobacteria were the first phototrophic organisms capable of producing oxygen. They are responsible for the conversion of Earth's atmosphere from anoxic to oxic ${ }^{[1]}$. For the production of biomass with specific characteristics, manipulation of the culture conditions is a key factor ${ }^{[2]}$.

Cyanobacteria are used for various purposes, e.g., for food supplements for humans ${ }^{[3]}$ and animals ${ }^{[4]}$. Some cultures are used in wastewater treatment ${ }^{[5]}$, in fixing carbon dioxide and in biocompound synthesis ${ }^{[6,7]}$. The biomass of Spirulina has been investigated for its hypocholesterolemic potential ${ }^{[8]}$, as a source of biofuels ${ }^{[9]}$ and for biopolymer production $^{[10-12]}$. Several genera and species of cyanobacteria, such as Dunaliella tertiolecta ${ }^{[1]}$, Aulosira fertilissima ${ }^{[12]}$, Nostoc muscorum ${ }^{[13]}$, Spirulina subsalsa ${ }^{[14]}$, Synechocystis sp ${ }^{[15]}$, Spirulina platensis ${ }^{[16]}$ and Synechococcus sp. ${ }^{[17]}$, are used for the production of biopolymers.

Bacteria and cyanobacteria have the capacity to produce polyhydroxyalkanoates (PHAs) ${ }^{[13,18]}$, which are biodegradable polyesters with potential use as polymeric materials ${ }^{[19]}$. Biodegradable polymers are alternative replacements for petrochemical polymers ${ }^{[20]}$.

Reducing the consumption of plastic materials is difficult because of their versatile properties. However, it is possible to replace the petrochemical polymers with alternative materials that have similar polymer properties but show rapid degradation after disposal ${ }^{[20]}$.

PHAs may positively change the scenario of global climate impact by reducing the amount of non-biodegradable polymers used ${ }^{[20]}$. Mixed cyanobacterial and bacterial cultures to produce PHAs are emerging due to the potential residuary use for growth and low installation cost towards a profitable production of polyhydroxyalkanoates. The growth of microalgae does not require large amounts of land and can occupy areas unsuitable for agriculture, thus not competing with food production, due to the possibility of using photobioreactors that maximize biomass production ${ }^{[21,22]}$.

The objective of this work was to select biopolymer-producing microalgae and to study the phase of cell growth in which maximum production occurs.

\section{Materials and Methods}

\subsection{Microorganisms and culture medium}

The microalgae used were Cyanobium sp., Nostoc ellipsosporum, Spirulina sp. LEB 18 and Synechococcus nidulans. The microalgal strain Nostoc ellipsosporum (B1453-79) was provided by the University of Göttingen (Germany). The cyanobacteria Cyanobium sp. ${ }^{[23]}$, Spirulina sp. LEB $18^{[24]}$ and Synechococcus nidulans ${ }^{[7]}$ belong to the Collection of Strains of the Laboratory of Biochemical Engineering of the Federal University of Rio Grande (FURG). Spirulina sp. LEB 18 was isolated from

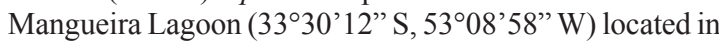
Santa Vitoria do Palmar/RS (Brazil). The cyanobacterium Synechococcus nidulans was isolated from a stabilization pond of the President Medici Thermoelectric Power Plant, located in Candiota/RS (Brazil) (2436'13"S, 52³2'43"W). Inocula of Cyanobium sp. and Nostoc ellipsosporum microalgae were maintained in BG-11 culture medium ${ }^{[25]}$, and Spirulina sp. LEB 18 and Synechococcus nidulans 
microalgae were maintained in Zarrouk culture medium ${ }^{[26]}$. All inoculations were adapted to their respective culture media for $30 \mathrm{~d}$ before the start of the experiments.

\subsection{Culture conditions}

The cultivations were performed in closed $2 \mathrm{~L}$ photobioreactors with a working volume of $1.5 \mathrm{~L}$ and continuous agitation by the injection of sterile air to avoid the precipitation of the biomass. For Nostoc ellipsosporum, Spirulina sp. LEB 18 and Synechococcus nidulans, the initial concentration was $0.15 \mathrm{~g} . \mathrm{L}^{-1}$, but for Cyanobium sp., the initial concentration was 0.2 g. $\mathrm{L}^{-1}$. The triplicate cultures were kept in a thermostated chamber at $30^{\circ} \mathrm{C}$ for $5,10,15,20$ and $25 \mathrm{~d}$, for a total of 15 experiments for each microalgae. The illuminance used was $41.6 \mu \mathrm{mol}_{\text {photons }} \cdot \mathrm{m}^{-2} \cdot \mathrm{s}^{-1}$ with a $12 \mathrm{~h}$ light/dark photoperiod maintained by $40 \mathrm{~W}$ fluorescent lamps.

\subsection{Analytical determinations}

Daily samples were collected aseptically for the monitoring of the cell concentration and $\mathrm{pH}$. Cell concentration was determined by optical density at $670 \mathrm{~nm}$ in a spectrophotometer (Quimis Q798DRM, Brazil) with a calibration curve relating the optical density to the dry weight of the microalgal biomass ${ }^{[27]}$. The $\mathrm{pH}$ determination was performed in digital $\mathrm{pH}$ meter (Quimis Q400H, Brazil) following AOAC methodology ${ }^{[28]}$.

\subsection{Determination of the crude biopolymer yield}

The crude biopolymer yield $\left(\mathrm{Y}_{\mathrm{CB}}\right)$ was calculated according to Equation 1, where $\mathrm{C}_{\mathrm{cbt}}$ is the concentration of crude biopolymers $\left(\mathrm{g} . \mathrm{L}^{-1}\right)$ at time $\mathrm{t}(\mathrm{d}), \mathrm{C}_{\mathrm{cb} 5}$ is the concentration of crude biopolymers (g. $\left.\mathrm{L}^{-1}\right)$ at time $5 \mathrm{~d}, \mathrm{t}$ is the time (d), and $\mathrm{t}_{5}$ is the time at $5 \mathrm{~d}$.

$$
\mathrm{Y}_{\mathrm{CB}}=\left(\mathrm{C}_{\mathrm{cbt}}-\mathrm{C}_{\mathrm{cb} 5}\right) /\left(\mathrm{t}-\mathrm{t}_{5}\right)
$$

\subsection{Extraction of crude biopolymers}

After 5, 10, 15, 20 and $25 \mathrm{~d}$ of experiment, the cultures were centrifuged at $7500 \mathrm{rpm}$ for $20 \mathrm{~min}$ at room temperature (Hitachi, Japan) to separate the wet biomass from the biopolymer of the culture medium. Later, for every $1 \mathrm{~g}$ of dry biomass, $100 \mathrm{~mL}$ of distilled water and $25 \mathrm{~mL}$ of sodium hypochlorite (10-12\% active chlorine $(\mathrm{w} / \mathrm{v}))$ were added to the wet biomass, and the solution was kept under stirring for $10 \mathrm{~min}$. The resulting suspension was centrifuged $(7500 \mathrm{rpm}$ for $20 \mathrm{~min}$ at room temperature). Then, the supernatant was discarded, and the precipitate was washed with $100 \mathrm{~mL}$ of distilled water. The sample was centrifuged again, and the supernatant was discarded. This process was repeated adding $50 \mathrm{~mL}$ of acetone. The final precipitate (crude biopolymers) was dried at $35{ }^{\circ} \mathrm{C}$ for $48 \mathrm{~h}$. The efficiency $(\eta)$ of crude biopolymers in relation to microalgal biomass (\%) was calculated using Equation 2, where $\mathrm{m}_{\mathrm{cb}}$ is the final mass of crude biopolymer obtained from the microalgal biomass $(\mathrm{g})$, and $\mathrm{m}_{\mathrm{ma}}$ is microalgal biomass $(\mathrm{g})$.

$$
\eta=\left(m_{\mathrm{cb}} * 100\right) / \mathrm{m}_{\mathrm{ma}}
$$

\subsection{Statistical analysis}

The results were processed by analysis of variance (ANOVA) and Tukey's test to compare the means of the parameters analyzed with a $95 \%$ confidence level.

\section{Results and Discussions}

The growth curves of cyanobacteria Cyanobium sp., Nostoc ellipsosporum, Spirulina sp. LEB 18 and Synechococcus nidulans (Figure 1) showed different behaviors in spite of each species having its own specific growth characteristics and different culture media. In preliminary tests, it was observed that when the microalga Cyanobium sp. was grown at low biomass concentrations $(0.15$ g.L.-1), it showed photoinhibition in its growth; therefore, the assays were carried out with an initial biomass concentration of 0.2 g. $\mathrm{L}^{-1}$, thereby preventing cell death and providing the lag phase of growth.

Spirulina sp. LEB 18 (Figure 1c) showed early stationary growth phase after $20 \mathrm{~d}$ of culture. For Cyanobium sp., Nostoc ellipsosporum and Synechococcus nidulans, the stationary phase of growth was not observed by the end of the $25 \mathrm{~d}$ of culture. To verify the growth phases of the microalgae Cyanobium sp., N. ellipsosporum and S. nidulans, it would be necessary to grow the cultures for a longer period. For large-scale production, such a long culture period is impractical for the production of biopolymers. Sharma and Mallick ${ }^{[29]}$ cultivated Nostoc muscorum microalgae in BG-11 medium with a phosphorus deficiency and addition of exogenous carbon sources and found an increase in the production of PHB. Yields of up to $8.6 \%$ (PHB) were found when the extraction of the polymer was performed in the early stationary phase of growth of the microalgae ( $21 \mathrm{~d}$ of culture), whereas in $\log$ phase, the yield was $6.1 \%$. Samantaray and Mallick ${ }^{[12]}$ cultivated the microalga Aulosira fertilissima during $14 \mathrm{~d}$ and observed an accumulation of $6.4 \%$ of PHB at the end of logarithmic growth phase.

The microalga Nostoc ellipsosporum presented a different behavior in its cell growth compared to the other microalgae under study. During the first $8 \mathrm{~d}$ of culture, it showed cell growth, then ceased and remained constant until the 17th d, after which it presented new cell growth. This growth pattern may have occurred because when the microalgae are under a particular nutrient limitation, they use a substrate from its own cell as a nutrient, enabling continued growth. If there is a lack of carbon, the microorganism can consume the biopolymer itself. In this case, it is believed that the biopolymer may have been consumed, because after the 10th $\mathrm{d}$ of cultivation, the yield of biopolymers was reduced (Table 1). Another nutrient that may have had an influence was nitrogen, whose release in the culture medium from amino acids of phycobiliproteins and chlorophyll can possibly allow cell maintenance to occur ${ }^{[30,31]}$.

The cyanobacterium Nostoc ellipsosporum presented a cell concentration less than the others but had higher efficiency (Table 1) and crude biopolymer yield (Table 2).

Among the microalgae under study, Nostoc ellipsosporum and Spirulina sp. LEB 18 stood out. These microalgae showed the higher efficiency of crude biopolymers (PHB) and did not differ significantly $(\mathrm{p}<0.05)$ each other from $15 \mathrm{~d}$. However, Nostoc ellipsosporum reached a crude biopolymer 


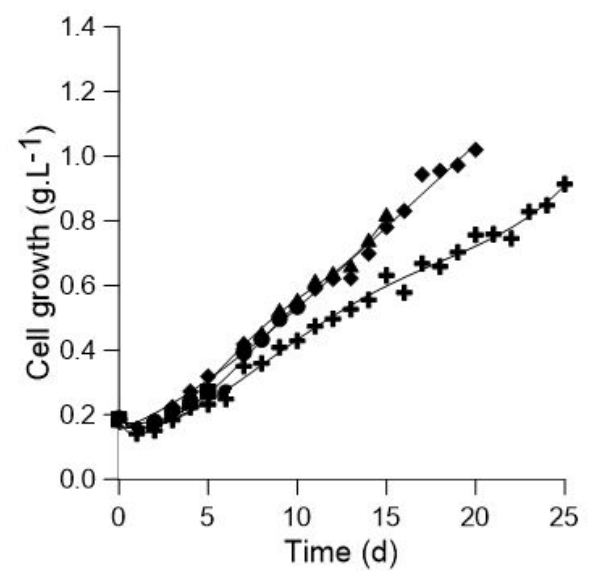

(a)

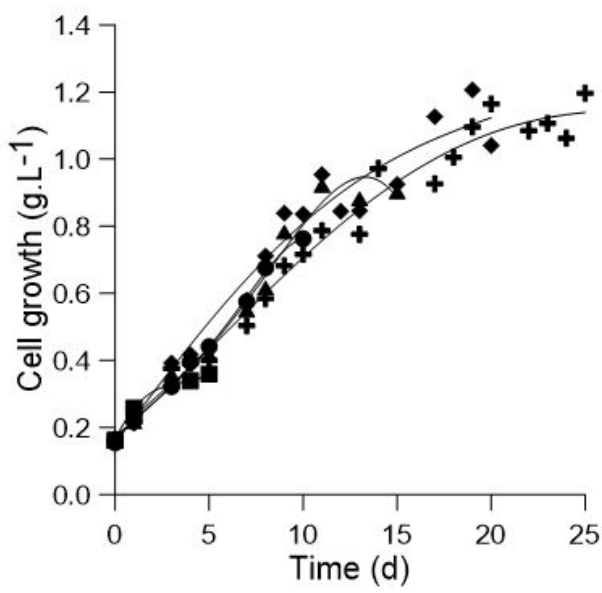

(c)

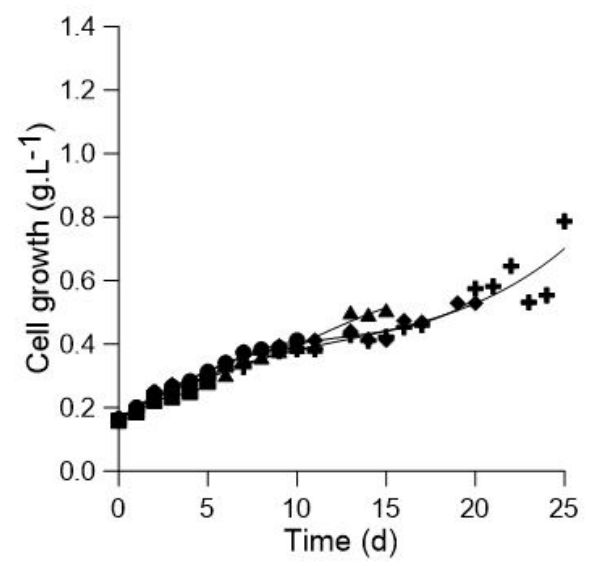

(b)

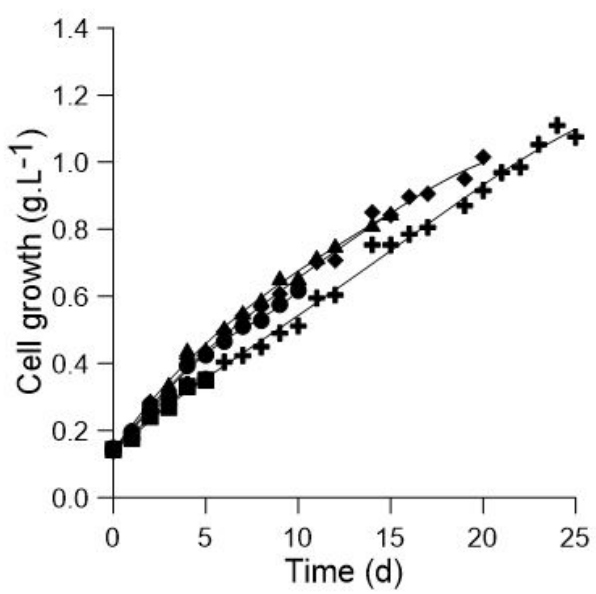

(d)

Figure 1. Growth curves of microalgae Cyanobium sp. (a) Nostoc ellipsosporum (b), Spirulina sp. LEB 18 (c) and Synechococcus nidulans (d) with $5(\bullet), 10(\bullet), 15(\boldsymbol{\Delta}), 20(\bullet)$ and $25(+)$ d of culture.

Table 1. Crude biopolymer efficiency $\left(\%, \mathrm{w} / \mathrm{w}^{*}\right)$ for microalgae at different culture times.

\begin{tabular}{ccccc}
\hline \multirow{2}{*}{ Time (d) } & \multicolumn{5}{c}{ Microalgae } \\
\cline { 2 - 5 } & Cyanobium sp. & N. ellipsosporum & Spirulina sp. LEB 18 & Sidulans \\
\hline 5 & $3.68 \pm 0.23^{\mathrm{aAB}}$ & $9.04 \pm 3.24^{\mathrm{aC}}$ & $5.82 \pm 2.02^{\mathrm{aB}}$ & $1.18 \pm 0.23^{\mathrm{aA}}$ \\
10 & $3.17 \pm 0.26^{\mathrm{abA}}$ & $19.27 \pm 1.18^{\mathrm{bB}}$ & $10.23 \pm 0.93^{\mathrm{aC}}$ & $8.83 \pm 0.06^{\mathrm{bC}}$ \\
15 & $2.75 \pm 0.40^{\mathrm{bA}}$ & $17.79 \pm 1.32^{\mathrm{bB}}$ & $20.62 \pm 3.17^{\mathrm{bB}}$ & $1.00 \pm 0.33^{\mathrm{aA}}$ \\
20 & $2.91 \pm 0.15^{\mathrm{abA}}$ & $13.41 \pm 3.80^{\mathrm{abB}}$ & $11.83 \pm 1.67^{\mathrm{aB}}$ & $10.21 \pm 1.95^{\mathrm{bB}}$ \\
25 & $3.12 \pm 0.30^{\mathrm{abA}}$ & $10.69 \pm 2.84^{\mathrm{aB}}$ & $11.86 \pm 2.43^{\mathrm{aB}}$ & $11.01 \pm 1.49^{\mathrm{cB}}$ \\
\hline
\end{tabular}

For the same letters, the averages do not differ significantly $(\mathrm{p}<0.05)$ by Tukey test. Lowercase letters compare the results in columns. Uppercase letters compare the results in the rows. *Values correspond to averages of results obtained in triplicate with their respective standard deviations.

Table 2. Crude biopolymer yield $\left(\mathrm{Y}_{\mathrm{cb}}, \mathrm{g}_{\mathrm{cb}} \cdot \mathrm{L}^{-1} \cdot \mathrm{d}^{-1}\right)$ for microalgae at different culture times.

\begin{tabular}{ccccc}
\hline \multirow{2}{*}{ Time (d) } & \multicolumn{4}{c}{ Microalgae } \\
\cline { 2 - 5 } & Cyanobium sp. & Nostoc ellipsosporum & Spirulina sp. LEB 18 & Synechococcus nidulans \\
\hline 5 & - & - & - & - \\
10 & $<0.01$ & 2.05 & 0.88 & 1.53 \\
15 & $<0.01$ & 0.87 & 1.48 & $<0.01$ \\
20 & $<0.01$ & 0.29 & 0.40 & 0.60 \\
25 & $<0.01$ & 0.08 & 0.30 & 0.49 \\
\hline
\end{tabular}


efficiency of $19.27 \%$ in $10 \mathrm{~d}$ and Spirulina sp. LEB 18 reached $20.62 \%$ in $15 \mathrm{~d}$ of culture. The crude biopolymer efficiency of Nostoc ellipsosporum was $2.05 \mathrm{~g} . \mathrm{L}^{-1} \cdot \mathrm{d}^{-1}$ at $10 \mathrm{~d}$, where as that of Spirulina sp. LEB 18 was $1.48 \mathrm{~g} \cdot \mathrm{L}^{-1} \cdot \mathrm{d}^{-1}$ at $15 \mathrm{~d}$ (Table 2). Panda et al. ${ }^{[15]}$ found that the cyanobacterium Synechocystis sp. PCC 6803 accumulated biopolymer PHB in its cells. It has been found that when cultured in BG-11 medium under phosphorus and/or nitrogen deficiency with the addition of exogenous carbon sources, this microalgae showed a higher yield $(4.5 \%)$ of PHB in the early stationary growth phase (at $21 \mathrm{~d}$ cultivation), while in the logarithmic phase, the yield was $2.9 \%$.

The microalga Cyanobium sp. did not achieve significant results $(\mathrm{p}>0.05)$ for the production of crude biopolymers. The cyanobacterium Synechococcus nidulans showed the highest PHB efficiency $(11.01 \pm 1.49 \%)$ at a greater time of growth (25 d) in relation to the microalgae Spirulinasp. LEB 18 and Nostoc ellipsosporum. Therefore, its use is less interesting compared to Nostoc ellipsosporum and Spirulina sp. LEB 18. Lower yields (3\%) of PHB were found by Sankhla et al. ${ }^{[32]}$ in the stationary phase of growth when studying the production of PHB by Brevibacillus invocatus MTCC 9039.

The lowest yields obtained in culture times greater than $10 \mathrm{~d}$ (Nostoc ellipsosporum) and $15 \mathrm{~d}$ (Spirulina sp. LEB 18) may be due to the depletion of nutrients from the medium, especially carbon, which leads to consumption of the biopolymers for cell growth and maintenance. The results showed the effect of culture time on the production of biopolymers. This difference in yield is associated with the fact that the production of the polymer depends on the availability of the source of carbon and energy, which vary as a function of the culture time. Bhati and Mallick ${ }^{[13]}$ studied the microalga Nostoc muscorum for the production of PHB-HV with yields of $16.6 \%$ in $10 \mathrm{~d}$ of incubation. For the same microalga, yields of different biopolymers were observed at different times using different carbon sources. When BG-11 medium was used with the addition of propionate, the highest yield was $12.6 \%$ in $21 \mathrm{~d}$ and $16.6 \%$ in $10 \mathrm{~d}$ with the addition of valerate. The highest yields were in the late exponential phase of growth. Mallick ${ }^{[33]}$ studied the production of PHB-HV in Nostoc muscorum using BG-11 medium with the addition of propionate yielding $28.2 \%$ of biopolymer in $14 \mathrm{~d}$ of culture (late exponential growth phase).

Several microalgae, especially cyanobacteria, are able to accumulate intracellular biopolymers, especially poly-3-hydroxybutyrate and poly (3-hydroxybutyrateco-3-hydroxyvalerate) belonging to the group of polyhydroxyalkanoates. By modifying the culture conditions, particularly the nutrients, one can divert the metabolic pathways, causing the microorganism to synthesize larger amounts of biopolymers.

Studies are being carried out with photosynthetic mixtures of bacteria and algae that accumulate PHA in conditions with different concentrations of nutrients, and these studies have achieved PHB yields of $20 \%$. The use of mixed photosynthetic culture (bacteria and microalgae) has emerged as an alternative system for the production of
PHA, potentially minimizing feed costs through the use of solar energy ${ }^{[34]}$.

The defatted biomass of microalgae Dunaliella tertiolecta was used for the production of biopolymers in different salt concentrations, obtaining a yield of $82 \%{ }^{[11]}$. High yields of biopolymers can be achieved using microalgae. It is possible to conclude that many microalgae are able to intracellularly accumulate PHB granules. However, different behaviors are observed due to the use of different microalgal sources and concentrations of nutrients and growth conditions.

\section{Conclusions}

This study showed that in order to produce biopolymers from microalgal cultures, the microalgae Spirulina sp. LEB 18 and Nostoc ellipsosporum would be the best candidates. Both microalgae had higher concentrations of biopolymers at short growth times (Spirulina sp. LEB 18, 20.62\% in $15 \mathrm{~d}$; Nostoc ellipsosporum, $19.27 \%$ in 10 d). Combining the growth of microalgae and biopolymer production is a strategy with the potential to significantly reduce environmental pollution problems, through both the use of industrial waste as a source of nutrients for the culture medium and the replacement of petrochemical origin polymers by biopolymers degradable and compostable when disposed of in the environment.

\section{Acknowledgements}

The authors would like to thank CNPq (National Council of Technological and Scientific Development), CGTEE (Company of Thermal Generation of Electric Power) and MCTI (Ministry of Science, Technology and Inovation) for their financial support of this study.

\section{References}

1. Madigan, M. T., Martinko, J. M., Dunlap, P. V., \& Clark, D. P. (2010). Microbiologia de Brock. Porto Alegre: Artmed.

2. Mata, T. M., Martins, A. A., \& Caetano, N. S. (2010). Microalgae for biodiesel production and other applications: a review. Renewable \& Sustainable Energy Reviews, 14(1), 217-232. http://dx.doi.org/10.1016/j.rser.2009.07.020.

3. Morais, M. G., Miranda, M. Z., \& Costa, J. A. V. (2006). Biscoitos de chocolate enriquecido com Spirulina platensis: características físico-química, sensorial e digestibilidade. Alimentos e Nutrição, 17(3), 333-340.

4. Silva, M. J., Figueiredo, B. R. S., Ramos, R. T. C., \& Medeiros, E. S. F. (2010). Food resources used by three species of fish in the semi-arid region of Brazil. Neotropical Ichthyology, 8(4), 825-833. http://dx.doi.org/10.1590/S1679-62252010005000010.

5. Córdoba, L. T., Bocanegra, A. R. D., Llorente, B. R., Hernández, E. S., Echegoyen, F. B., Borja, R., Bejines, F. R., \& Morcillo, M. F. C. (2008). Batch culture growth of Chlorella zofingiensis on effluent derived from two-stage anaerobic digestion of two-phase olive mill solid waste. Journal of Biotechnology, 11(2), 1-8. http://dx.doi.org/10.2225/vol11-issue2-fulltext-1.

6. Morais, M. G., \& Costa, J. A. V. (2008). Bioprocessos para remoção de dióxido de carbono e óxido de nitrogênio por microalgas visando a utilização de gases gerados durante a combustão do carvão. Química Nova, 31(5), 1038-1042. http:// dx.doi.org/10.1590/S0100-40422008000500017.

7. Radmann, E. M., Camerini, F. V., Santos, T. D., \& Costa, J. A. $\mathrm{V}$. (2011). Isolation and application of $\mathrm{SO}_{\mathrm{x}}$ and $\mathrm{NO}_{\mathrm{x}}$ resistant 
microalgae in biofixation of $\mathrm{CO}_{2}$ from thermoelectricity plants Energy Conversion and Management, 52(10), 3132-3136. http://dx.doi.org/10.1016/j.enconman.2011.04.021.

8. Colla, L. M., Muccillo-Baisch, A. L., \& Costa, J. A. V. (2008). Spirulina platensis effects on the levels of total cholesterol, HDL and triacylglycerol in rabbits fed with a hypercholesterolemic diet. Brazilian Archives of Biology and Technology, 51(2), 405411. http://dx.doi.org/10.1590/S1516-89132008000200022.

9. Oltra, C. (2011). Stakeholder perceptions of biofuels from microalgae. Energy Policy, 39(3), 1774-1781. http://dx.doi org/10.1016/j.enpol.2011.01.009.

10. Martins, R. G., Gonçalves, I. S., Morais, M. G., \& Costa, J. A. V. (2014). Bioprocess engineering process aspects of biopolymer production by the cyanobacterium Spirulina strain LEB 18. International Journal of Polymer Science, 2014, 1-6. http://dx.doi.org/10.1155/2014/895237.

11. Goo, B. G., Baek, G., Choi, D. J., Park, Y. I., Synytsya, A., Bleha, R., Seong, D. H., Lee, C. G., \& Park, J. K. (2013). Characterization of a renewable extracellular polysaccharide from defatted microalgae Dunaliella tertolecta. Bioresource Technology, 129, 343-350. PMid:23262010. http://dx.doi. org/10.1016/j.biortech.2012.11.077.

12. Samantaray, S., \& Mallick, N. (2012). Production and characterization of poly- $\beta$-hidroxybutyrate (PHB) polymer from Aulosira fertilissima. Journal of Applied Phycology, 24(4), 803-814. http://dx.doi.org/10.1007/s10811-011-9699-7.

13. Bhati, R., \& Mallick, N. (2012). Production and characterization of poly(3-hydroxybutyrate-co-3-hydroxyvalerate) co-polymer by a $\mathrm{N}_{2}$-fixing cyanobacterium, Nostoc muscorum Agardh. Journal of Chemical Technology and Biotechnology, 87(4), 505-512. http://dx.doi.org/10.1002/jctb.2737.

14. Shrivastav, A., Mishra, S. K., \& Mishra, S. (2010). Polyhydroxyalkanoates (PHA) synthesis by Spirulina subsalsa from Gujarat coast of India. International Journal of Biological Macromolecules, 46(2), 255-260. PMid:20060853. http:// dx.doi.org/10.1016/j.ijbiomac.2010.01.001.

15. Panda, B., Jain, P., Sharma, L., \& Mallick, N. (2006). Optimization of cultural and nutritional conditions for accumulation of poly$\beta$-hydroxybutyrate in Synechocystis sp. PCC 6803. Bioresource Technology, 97(11), 1296-1301. PMid:16046119. http://dx.doi. org/10.1016/j.biortech.2005.05.013.

16. Jau, M.-H., Yew, S.-P., Toh, P. S. Y., Chong, A. S. C., Chu, W.-L., Phang, S.-M., Najimudin, N., \& Sudesh, K. (2005). Biosynthesis and mobilization of poly(3-hydroxybutyrate) $[\mathrm{P}(3 \mathrm{HB})]$ by Spirulina platensis. International Journal of Biological Macromolecules, 36(3), 144-151. PMid:16005060. http://dx.doi.org/10.1016/j.ijbiomac.2005.05.002.

17. Nishioka, M., Nakai, K., Miyake, M., Asada, Y., \& Taya, M. (2001). Production of poly- $\beta$-hydroxybutyrate by thermophilic cyanobacterium, Synechococcus sp. MA19, under phosphatelimited conditions. Biotechnology Letters, 23(14), 1095-1099. http://dx.doi.org/10.1023/A:1010551614648.

18. Mohammadi, M., Hassan, M. A., Phang, L.-Y., Shirai, Y., Man, H. C., \& Ariffin, H. (2012). Intracellular polyhydroxyalkanoates recovery by cleaner halogen-free methods towards zero emission in the palm oil mill. Journal of Cleaner Production, 37,353-360. http://dx.doi.org/10.1016/j.jclepro.2012.07.038.

19. Laycock, B., Halley, P., Pratt, S., Werker, A., \& Lant, P. (2014). The chemomechanical properties of microbial polyhydroxyalkanoates. Progress in Polymer Science, 39(3-4), 397-442. http://dx.doi.org/10.1016/j.progpolymsci.2013.06.008.

20. Chanprateep, S. (2010). Current trends in biodegradable polyhydroxyalkanoates. Journal of Bioscience and Bioengineering, 110(6), 621-632. PMid:20719562. http://dx.doi.org/10.1016/j. jbiosc.2010.07.014.
21. Satyanarayana, A. B., Mariano, A. B., \& Vargas, J. V. C. (2011). A review on microalgae, a versatile source for sustainable energy and materials. International Journal of Energy Research, 35(4), 291-311. http://dx.doi.org/10.1002/er.1695.

22. Nonhebel, S. (2005). Renewable energy and food supply: will there be enough land? Renewable \& Sustainable Energy Reviews, 9(2), 191-201. http://dx.doi.org/10.1016/j.rser.2004.02.003.

23. Henrard, A. A., Morais, M. G., \& Costa, J. A. V. (2011). Vertical tubular photobioreactor for semicontinuous culture of Cyanobium sp. Bioresource Technology, 102(7), 4897-4900. PMid:21295968. http://dx.doi.org/10.1016/j.biortech.2010.12.011.

24. Morais, M. G., Reichert, C. C., Dalcanton, F., Durante, A. J., Marins, L. F., \& Costa, J. A. V. (2008). Isolation and characterization of a new Arthrospira strain. Zeitschrift für Naturforschung, 63(1-2), 144-150. PMid:18386504.

25. Rippka, R., Deruelles, J., Waterburry, J. B., Herdman, M., \& Stanier, R. Y. (1979). Generic assignments, strain histories and properties of pure cultures of cyanobacteria. Journal of General Microbiology, 111, 1-61. http://dx.doi.org/10.1099/00221287111-1-1.

26. Zarrouk, C. (1966). Contribution à l'étude d'une cyanophycée: influence de divers facteurs physiques et chimiques sur la croissance et la photosynthèse de Spirulina maxima Geitler (Ph.D. Thesis). University of Paris, France.

27. Costa, J. A. V., de Morais, M. G., Dalcanton, F., Reichert, C. C., \& Durante, A. J. (2006). Simultaneous cultivation of Spirulina platensis and the toxigenic, cyanobacteria Microcystis aeruginosa. Zeitschrift für Naturforschung, 61(1-2), 105-110. PMid:16610226.

28. Association of Official Analytical Chemists-AOAC. (2000). Official methods of analysis of the Association of Official Analytical Chemists. 17th ed. In W. Horwitz (Ed.), Maryland: Association of Official Analytical Chemists.

29. Sharma, L., \& Mallick, N. (2005). Accumulation of poly- $\beta$ hydroxybutyrate in Nostoc muscorum: regulation $\mathrm{pH}$, lightdark cycles, N and P status abd carbon sources. Bioresource Technology, 96(11), 1304-1310. PMid:15734319. http://dx.doi. org/10.1016/j.biortech.2004.10.009.

30. Jiang, L., Luo, S., Fan, X., Yang, Z., \& Guo, R. (2011). Biomass and lipid production of marine microalgae using municipal wastewater and high concentration of $\mathrm{CO}_{2}$. Applied Energy, 88(10), 3336-3341. http://dx.doi.org/10.1016/j. apenergy.2011.03.043.

31. Wu, G. F., Wu, Q. Y., \& Shen, Z. Y. (2001). Accumulation of poly- $\beta$-hydroxybutyrate in cyanobacterium Synechocystis sp. PCC6803. Bioresource Technology, 76(2), 85-90. PMid:11131804. http://dx.doi.org/10.1016/S0960-8524(00)00099-7.

32. Sankhla, I. S., Bhati, R., Singh, A. K., \& Mallick, N. (2010). Poly(3-hydroxybutyrate-co-3-hydroxyvalerate) co-polymer production from a local isolate, Brevibacillus invocatus MTCC 9039. Bioresource Technology, 101(6), 1947-1953. PMid:19900805. http://dx.doi.org/10.1016/j.biortech.2009.10.006.

33. Mallick, N., Gupta, S., Panda, B., \& Sen, R. (2007). Process optimization for poly(3-hydroxybutyrate-co-3-hydroxyvalerate) co-polymer production by Nostoc muscorum. Biochemical Engineering Journal, 37(2), 125-130. http://dx.doi.org/10.1016/j. bej.2007.04.002

34. Fradinho, J. C., Domingos, J. M. B., Carvalho, G., Oehmen, A., $\&$ Reis, M. A. M. (2013). Polyhydroxyalkanoates production by a mixed photosynthetic consortium of bacteria and algae. Bioresource Technology, 132, 146-153. PMid:23399498. http:// dx.doi.org/10.1016/j.biortech.2013.01.050. 